\title{
Identification of a small molecule 1,4-bis-[4-(3- phenoxy-propoxy)-but-2-ynyl]-piperazine as a novel inhibitor of the transcription factor p53
}

Xin LIU ${ }^{1, \#}$, Ying ZHANG ${ }^{2, \#}$, Man TONG ${ }^{1}$, Xiu-ying LIU ${ }^{1,3}$, Guan-zheng LUO $^{1}$, Dong-fang XIE ${ }^{1}$, Shao-fang REN ${ }^{1}$, Dong-hui BAI ${ }^{2,3}$, Liu WANG ${ }^{2}$, Qi ZHOU ${ }^{2}$, Xiu-jie WANG ${ }^{1, *}$

${ }^{1}$ Center for Molecular Systems Biology, Institute of Genetics and Developmental Biology, Chinese Academy of Sciences, Beijing 100101, China; 'State Key Laboratory of Reproductive Biology, Institute of Zoology, Chinese Academy of Sciences, Beijing 100101, China; ${ }^{3}$ University of Chinese Academy of Sciences, Beijing 100049, China

Aim: To identify novel small compound inhibitor of p53 protein.

Methods: Mouse embryonic fibroblasts (MEF) and mouse embryonic stem (ES) cells were tested. Cell proliferation rate was determined using a Cell Proliferation Kit. The mRNA and protein levels of p53-related genes were measured using real-time PCR and Western blotting, respectively. Global response in the p53 signaling network was analyzed using Illumina whole-genome expression BeadChips. Results: Treatment of MEF cells with a small molecule 1,4-bis-[4-(3-phenoxy-propoxy)-but-2-ynyl]-piperazine (G5) at $10 \mu \mathrm{mol} / \mathrm{L}$ for $24 \mathrm{~h}$ markedly reduced the mRNA and protein levels of the p53 downstream genes MDM2 and p21. In G5-treated ES cells, a total of 372 differentially expressed genes were identified, and 18 among them were direct downstream genes of p53; 6 out of 9 p53-repressed genes were upregulated, and 5 out of 9 p53-activated genes were downregulated. In both MEF cells and ES cells, treatment of with G5 $(10 \mu \mathrm{mol} / \mathrm{L})$ up to $48 \mathrm{~h}$ neither affected the proliferation rate nor caused morphological alterations.

Conclusion: G5 inhibits p53 activity and simultaneously preserves the normal growth and proliferation of cells, therefore is a new compound for studies of p53-mediated cell manipulation.

Keywords: 1,4-bis-[4-(3-phenoxy-propoxy)-but-2-ynyl]-piperazine; tumor suppressor protein; p53; p53 inhibitor; embryonic fibroblast; embryonic stem cell; proliferation

Acta Pharmacologica Sinica (2013) 34: 805-810; doi: 10.1038/aps.2013.61

\section{Introduction}

The p53 protein regulates cell-cycle arrest, apoptosis, and senescence $^{[1]}$. As the most important tumor suppressor, the normal function of $\mathrm{p} 53$ is vital for preventing the genome from accumulating mutations and for inducing reversible cell-cycle arrest or apoptosis in severely injured cells ${ }^{[2,3]}$. In addition to the growth regulation and "genome guardian" functions of p53 in differentiated somatic cells, recent studies have shown that p53 plays essential roles in regulating stem cell homeostasis ${ }^{[4]}$ and cell reprogramming ${ }^{[5]}$. The functions of p53 in regulating both the proliferation and differentiation abilities of stem cells have been characterized. Several lines of evidence have shown that p53 can restrict embryonic stem (ES) cell proliferation ${ }^{[6]}$, promote ES cell differentiation ${ }^{[7-9]}$ and impede the reprogramming of differentiated somatic cells into

\footnotetext{
\# These authors contributed equally to this work.

* To whom correspondence should be addressed.

E-mail xjwang@genetics.ac.cn

Received 2013-01-22 Accepted 2013-05-02
}

induced pluripotent stem cells ${ }^{[10,11]}$.

Because of the essential roles of p53 in regulating normal cell growth, stress and DNA damage response, as well as stem cell homeostasis and cell reprogramming, accurate manipulation of p53 activity will have an important effect on researchers related to cancer and many other diseases, as well as on stem cell biology and cell reprogramming. Thus, efforts have been made to identify small molecules that can activate or inhibit the activity of both wildtype and mutated $\mathrm{p} 53^{[12-14]}$. However, the currently available small molecules that target p 53 usually lead to complete inhibition or activation of p53 function ${ }^{[15-20]}$, resulting in abnormal cell behaviors. For example, it has been shown that the p53 inhibitor Pifithrin-a will arrest the cell cycle and suppress the self-renewal ability of embryonic stem cells $^{[21]}$, whereas the global activation of p53 induced by the p53 activator nutlin leads to the rapid differentiation of human ES cells ${ }^{[8]}$. Thus, small molecules that can partially alter the activity of p53 without causing dramatic changes in cellular properties will be better tools for p53 manipulation and functional studies. 
Here, we identified the small molecule G5 as a novel inhibitor of p53. G5 can effectively repress the transcriptional regulatory activity of p53 in mouse embryonic fibroblasts (MEFs) and mouse ES cells, as shown by the corresponding expression changes in p53 downstream genes. However, inhibition of p53 by G5 did not impede the normal growth and proliferation of these cells.

\section{Materials and methods}

Derivation and culture of mouse embryonic fibroblasts and mouse embryonic stem cells

MEF cells were derived from CF1 mice as previously described $^{[22]}$. The ES cell line (ESC2) was obtained according to a previous study ${ }^{[23]}$. All of the animal studies were performed according to the guidelines approved by the Beijing Association on Laboratory Animal Care. Cells were seeded into 96-well and 24-well plates, as well as 60-mm dishes (Corning). MEF cells were cultured in DMEM supplemented with $10 \%$ FBS, $0.1 \mathrm{mmol} / \mathrm{L}$ nonessential amino acids (NEAA), and $0.1 \mathrm{mmol} / \mathrm{L} \mathrm{L}$-glutamine (Invitrogen). ES cells (ESC2) were cultured in DMEM supplemented with 15\% FBS, $0.1 \mathrm{mmol} / \mathrm{L}$ $\beta$-mercaptoethanol, $1000 \mathrm{U} / \mathrm{mL}$ leukemia inhibitory factor (LIF) and $0.1 \mathrm{mmol} / \mathrm{L}$ NEAA. All of the cells were cultured at $37^{\circ} \mathrm{C}$ in a humidified chamber with $5 \% \mathrm{CO}_{2}$ (Thermo). Small molecules were dissolved at $20 \mathrm{mmol} / \mathrm{L}$ (storage concentration) in DMSO (Sigma). Under conditions of serum starvation, MEF and ES cells were rinsed with $1 \times$ PBS (Invitrogen). MEF cells were then transferred into serum-free medium consisting of DMEM supplemented with $0.1 \mathrm{mmol} / \mathrm{L}$ NEAA and $0.1 \mathrm{mmol} / \mathrm{L}$ L-glutamine, and ES cells were transferred into serum-free medium consisting of DMEM with $0.1 \mathrm{mmol} / \mathrm{L}$ $\beta$-mercaptoethanol, plus $1000 \mathrm{U} / \mathrm{mL} \mathrm{LIF}$ and $0.1 \mathrm{mmol} / \mathrm{L}$ NEAA. The cells were serum-starved for $24 \mathrm{~h}$, and then 10 $\mu \mathrm{mol} / \mathrm{L}$ of the small compound was added to the serumfree medium and applied to the cells for continuous culture. Serum-free medium with $0.05 \%(v / v)$ DMSO was also applied to the control cells. The cells were observed and imaged using a Leica microscope.

\section{Cell proliferation assays}

The proliferation rate of the cells was determined using a Cell Proliferation Kit (MTT, Beyotime, Haimen, China) according to the manufacturer's instructions. Briefly, control MEF and ES cells (cultured in DMEM with 0.05\% DMSO) and compound-treated MEF and ES cells (cultured in DMEM with $10 \mu \mathrm{mol} / \mathrm{L}$ compound and $0.05 \%$ DMSO) were incubated in a 96-well plate with $100 \mu \mathrm{L}$ of culture medium per well. Ten microliters of the MTT labeling reagent (final concentration of $0.5 \mathrm{mg} / \mathrm{mL}$ ) was added to each well after $24 \mathrm{~h}$ or $48 \mathrm{~h}$ of cell culture. After incubating the plate for $4 \mathrm{~h}$ at $37^{\circ} \mathrm{C}$ with $5 \%$ $\mathrm{CO}_{2}, 100 \mu \mathrm{L}$ of the MTT solubilization solution was added to each well, and the plate was incubated at $37^{\circ} \mathrm{C}$ for another $4 \mathrm{~h}$. The formation of purple formazan crystals, which are proportional to the number of metabolically active viable cells, was measured using microplate reader (Beckman Coulter DTX880) at a wavelength of $570 \mathrm{~nm}$.

\section{RNA extraction and real-time PCR}

The total RNA of the control MEF and ES cells and the compound-treated MEF and ES cells were isolated using TRIzol Reagent (Invitrogen, USA) according to the manufacturer's protocol. Next, $1 \mu \mathrm{g}$ of RNA from each sample was extracted, reverse transcribed into complementary DNA (cDNA) using random primers, and subjected to real-time polymerase chain reaction (PCR). Real-time PCR was performed using the Stratagene Mx3000p QPCR System (Genetimes). The reactions were incubated in a 96 -well plate at $95^{\circ} \mathrm{C}$ for $10 \mathrm{~min}$, followed by 40 cycles of $95^{\circ} \mathrm{C}$ for $15 \mathrm{~s}$ and $60^{\circ} \mathrm{C}$ for $1 \mathrm{~min}$. All of the reactions were run in triplicate. The primer pairs used were MDM2 forward primer, 5'-CCCCGTGAAGGGTCGGAA-3' and reverse primer, 5'-GTTGGTATTGCACATTGGCCTGG-3'; p21 forward primer, 5'-CATTCAGAGCCACAGGCACC-3' and reverse primer, 5'-CCATGAGCGCATCGCAATC-3'; GAPDH forward primer, 5'-TCCCACTCTTCCACCTTCGATGC-3' and reverse primer, 5'-GGGTCTGGGATGGAAATTGTGAGG-3'.

\section{Western blot analysis}

Western blotting was performed as previously described ${ }^{[24]}$. Commercial antibodies for MDM2 (Santa Cruz catalog No 965) and p21 (Epitomics catalog No 2990-1) were used in this study.

\section{Global gene-expression profiling analysis}

Total RNA was extracted from mouse ES cells using TRIzol Reagent (Invitrogen, USA) according to the manufacturer's protocol. Ten micrograms of biotin-labeled cRNA (antisense RNA) was hybridized to a GeneChip Mouse WG-6 2.0 expression BeadChip. Three biologically replicated hybridizations were performed for the sample and control cells, respectively. After hybridization and washing, the gradation of the array chips was measured using a BeadArray Reader and converted into an expression signal using the Illumina Genome Studio V2011.1 software. The signal file created from each chip scanning was processed using the lumi package from Bioconductor for normalization and differentially gene expression analysis. Normalization was performed using the lumiExpresso method from the lumi package. The $t$-test and log-odds analyses of differential gene expression were performed using the empirical Bays shrinkage of the standard errors towards a common value with a threshold $P$-value $<0.05$ and a fold change $>1.3$.

\section{Results}

Identification of G5 as a p53 inhibitor

To search for effective inhibitors of p53, we first selected the coordinate structure of the human p53 protein as the receptor in a virtual screening approach (Figure 1). Approximately 13000 compounds (Specs chemistry database; Delft, Netherlands) were screened for their ability to bind to p53 using the docking algorithm Libdock (Accelrys Software Inc, San Diego, CA, USA). The 40 top-ranked molecules were selected as candidate $\mathrm{p} 53$ inhibitors for cell assays.

The MDM2 gene is a direct downstream target of p53 and has been used as a classical reporter of p53 activity for many years $^{[12]}$. Thus, we selected MDM2 as a reporter of p53 activity and measured the expression levels of the MDM2 gene and 


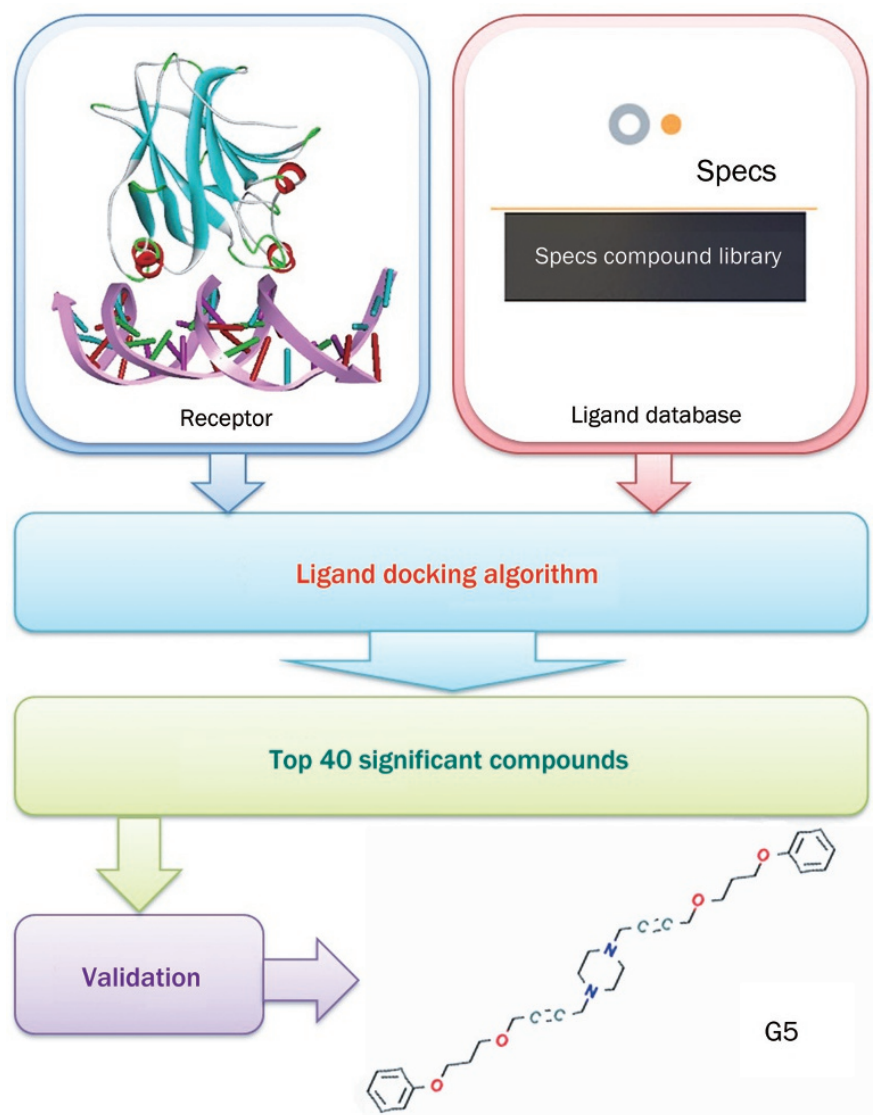

Figure 1. Flow diagram of the in silico compound screening methodology. The chemical structure of $\mathrm{G} 5$ is presented.

MDM2 protein in MEF cells after treatment with selected compounds. In the initial screen, we treated MEF cells cultured in DMEM supplemented with 10\% FBS with $10 \mu \mathrm{mol} / \mathrm{L}$ of each candidate compound, in the absence of any medium change and drug replacement. After $24 \mathrm{~h}$ of treatment, we assayed the p53 activation level by MDM2 gene expression using real-time PCR. Among the assayed compounds, a small molecule called G5, 1,4-bis-[4-(3-phenoxy-propoxy)-but-2-ynyl]-piperazine (Figure 1), significantly reduced the expression level of MDM2 by over $60 \%$ compared to the control MEF cells treated with the same concentration of DMSO $(P<0.01$, Student's $t$-test $)$ (Figure 2A). These findings implicated G5 as a potential p53 inhibitor.

\section{G5 repressed the expression of p53 downstream genes in MEF} cells

To further validate the function of G5, we examined the inhibitory ability of G5 on MDM2 expression at the protein level. Consistent with the expression change in MDM2 mRNA (Figure 2A), a clear reduction in MDM2 protein levels were also observed in G5-treated MEF cells compared to the control cells (Figure 2B).

To further examine the effectiveness of G5 and the feasibility of applying it to stem cell studies ${ }^{[25]}$, we examined its ability to suppress the p53-downstream gene p21. The expression levels
A

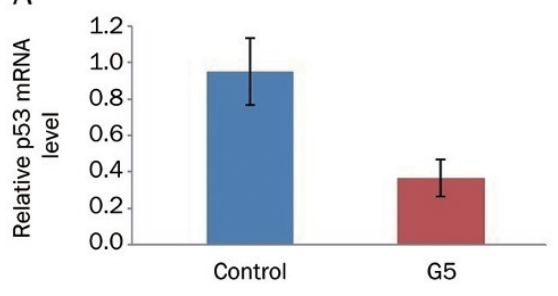

B

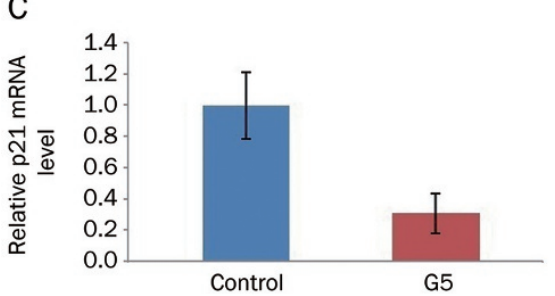

D

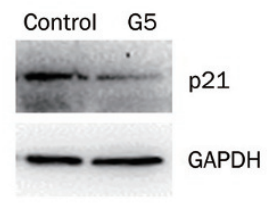

Figure 2. Inhibitory effects of G5 on the p53 downstream genes in MEF cells treated with G5 for $24 \mathrm{~h}$. (A) The mRNA expression level of a p53 downstream gene MDM2 in the control and G5-treated MEF cells. (B) The protein expression level of MDM2 in the control and G5-treated MEF cells. (C) The mRNA expression level of the p53 downstream gene p21 in the control and G5-treated MEF cells. (D) The protein expression level of p21 protein in the control and G5-treated MEF cells.

of both p21 mRNA and protein were remarkably repressed in G5-treated MEF cells compared to controls (Figure 2C and 2D).

G5 regulated global gene expression downstream of p53 signaling pathways in ES cells

To further evaluate whether G5 can induce a global response in the p53 signaling network in ES cells, we examined the gene expression profiles of G5-treated and control ES cells using Illumina whole-genome expression BeadChips. A total of 372 differentially expressed (DE) genes were identified in G5-treated ES cells compared to control cells using a fold change $>1.3$ and a $P$-value $<0.05$ (Student's $t$-test) as cutoffs. Among these genes, 18 were direct downstream genes of p53 as identified by the Pathway Studio software (Figure 3A). Six out of nine p53-repressed genes were upregulated (Figure $3 \mathrm{~B})$, and 5 out of 9 p53-activated genes were downregulated under G5 treatment (Figure 3C). It has been suggested that the repression of p53 activity can promote the pluripotency maintenance of ES cells ${ }^{[4]}$. From the microarray data, we also observed that the expression of genes facilitating differentiation, such as Sox21, which is a suppressor of the pluripotent gene Sox $2^{[26]}$, was repressed under G5 treatment. In contrast, the expression of several pluripotent factors, such as Klf4, Klf5 ${ }^{[27]}$ and Med12 ${ }^{[28]}$, was upregulated in G5-treated ES cells (Table 1).

MEF and ES cells with G5 treatment displayed a normal proliferation rate

It has been reported that the widely used p53 inhibitor Pifithrin-a induces the growth arrest of cells ${ }^{[21]}$. To examine whether G5 affects the proliferation ability of MEF and ES 
A

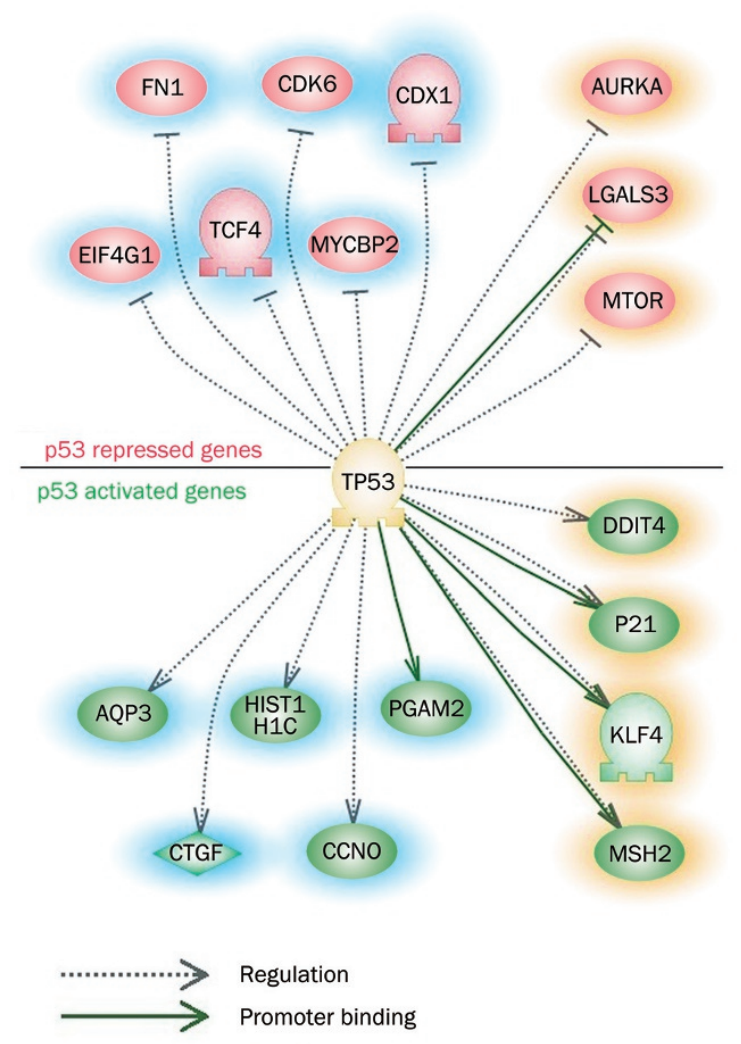

B

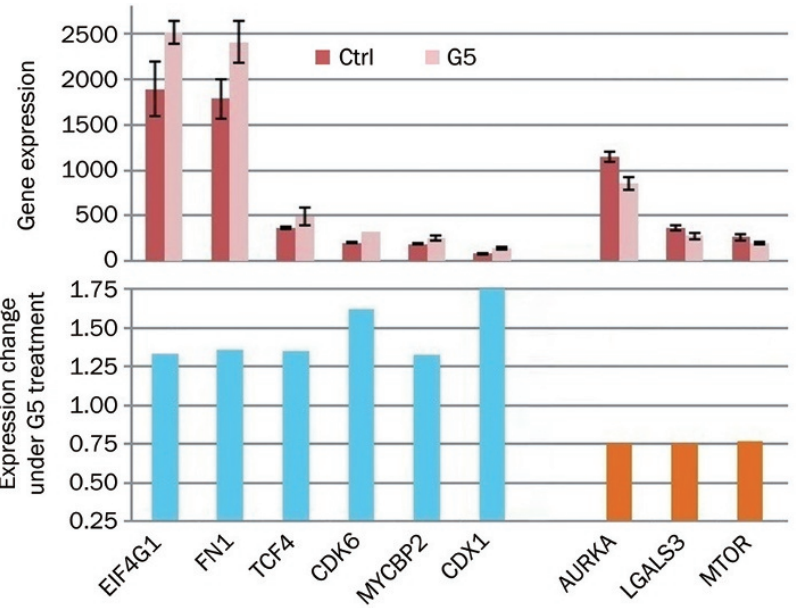

C

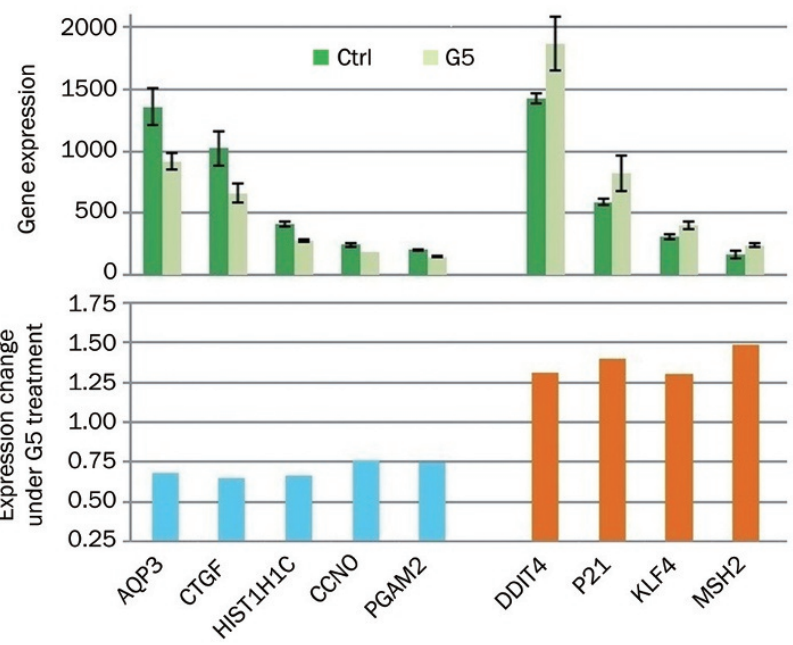

Figure 3. Effect of G5 on the p53 signaling network in ES cells. (A) A diagram of the effects of G5 on p53 direct target genes in ES cells. p53 direct downstream genes and the regulatory relationship between p53 and downstream genes were identified using the Pathway Studio software (Ariadne Genomics, Inc). Genes with expression changes consistent with the reported regulatory relationship with p53 are shown in blue, and genes with expression changes inconsistent with the reported regulatory relationship with p53 are shown in orange. (B) Effect of G5 on the mRNA expression levels of p53-repressed genes. (C) Effect of G5 on the mRNA expression levels of p53-activated genes. In both B and C, the expression changes were calculated as the ratio of normalized expression values of genes in the G5-treated cells vs the control cells. The blue bars represent genes with expression changes consistent with the reported regulatory relationship with p53, orange bars represent genes with expression changes inconsistent with the reported regulatory relationship with $\mathrm{p} 53$.

Table 1. The effects of G5 in modulating the expression of key pluripotent factors of mouse ES cells. The pluripotency inhibitory gene Sox21 is shown in bold.

\begin{tabular}{lccc}
\hline Genes & $\begin{array}{c}\text { Expression } \\
\text { abundance } \\
(\text { G5 })\end{array}$ & $\begin{array}{c}\text { Expression } \\
\text { abundance } \\
\text { (Ctrl) }\end{array}$ & $\begin{array}{c}\text { Fold } \\
\text { Change } \\
(\text { G5/Ctrl) }\end{array}$ \\
\hline KIf4 & $398.27 \pm 33.47$ & $305.40 \pm 24.00$ & 1.30 \\
KIf5 & $7301.65 \pm 158.88$ & $4677.32 \pm 331.57$ & 1.56 \\
Med12 & $340.78 \pm 18.44$ & $257.62 \pm 21.42$ & 1.32 \\
Sox21 & $\mathbf{5 6 3 . 1 9 \pm 3 7 . 8 2}$ & $\mathbf{8 3 7 . 1 1 \pm 9 2 . 8 1}$ & $\mathbf{0 . 6 7}$ \\
\hline
\end{tabular}

cells, we treated these cells with $10 \mu \mathrm{mol} / \mathrm{L}$ G5 dissolved in $0.05 \%(v / v$, concentration in final culture) DMSO and then characterized their morphology and monitored their repli- cative capacity. After $24 \mathrm{~h}$ of treatment, we found that the G5-treated MEF cells exhibited elongated and normal threedimensional cell shapes, resembling typical fibroblast morphology, and showed no observable differences compared to control MEF cells treated with the same concentration of DMSO (Figure 4A). In addition, G5-treated ES cells showed no observable morphological differences from the ES cells cultured in the same DMSO concentration (Figure 5A). When examined at $48 \mathrm{~h}$ after treatment, no growth rate or morphological differences were observed between the G5-treated and control cells for both MEF cells (Figure 4B) and ES cells (Figure $5 B)$.

To further validate the observation that G5 treatment did not reduce the proliferation rate of MEF and ES cells, we performed the MTT assay. The optical density absorbance values $(O D)$ of G5-treated MEF cells and the control cells measured at $570 \mathrm{~nm}$ were 0.21 and 0.20 , respectively, after $24 \mathrm{~h}$ of treat- 

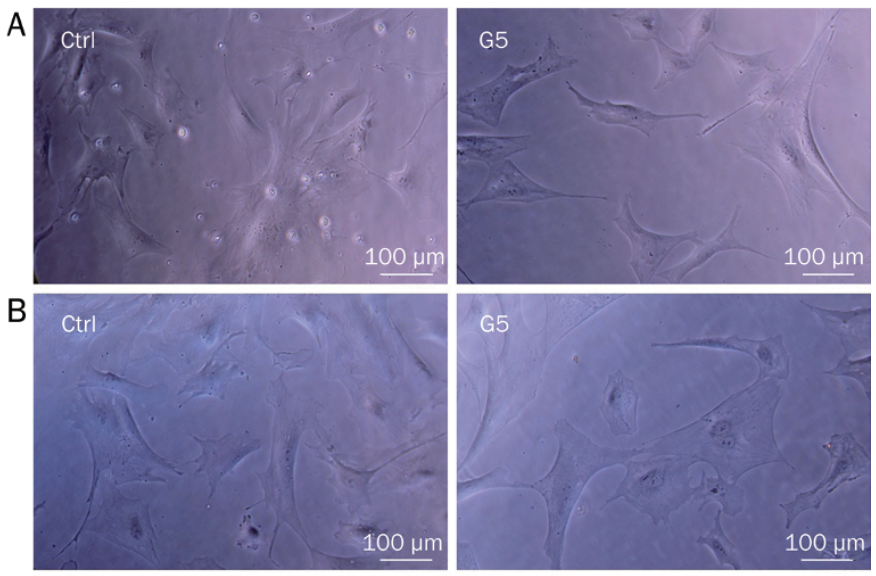

C

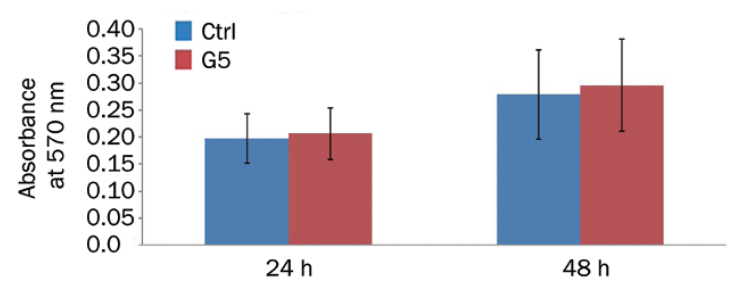

Figure 4. Effects of G5 on the morphology and proliferation rate of MEF cells. (A) The morphology of MEF cells with and without G5 treatment after $24 \mathrm{~h}$ of serum starvation. (B) The morphology of the MEF cells with and without $\mathrm{G} 5$ treatment after $48 \mathrm{~h}$ of serum starvation. (C) Examination of the cell proliferation rate on MEF cells treated with G5 for $24 \mathrm{~h}$ and $48 \mathrm{~h}$. The number of viable cells was determined using the MTT assay.

ment. After $48 \mathrm{~h}$ of treatment, the $O D$ readings were 0.30 and 0.28 in the G5-treated and control MEF cells, respectively (Figure 4C). There was no significant difference between the G5-treated and control groups $\left(P_{24 \mathrm{~h}}=0.83 ; P_{48 \mathrm{~h}}=0.82 ; P>0.05\right.$, Student's $t$-test). Similarly, the proliferation rate of the ES cells with and without $G 5$ treatment had no significant difference $\left(P_{24 \mathrm{~h}}=0.57 ; P_{48 \mathrm{~h}}=0.88 ; P>0.05\right.$, Student's $t$-test) (Figure 5C). These results demonstrated that G5 did not affect the proliferation rate of the cells.

\section{Discussion}

The p53 protein plays essential roles in regulating normal cell growth and preventing cells from DNA damage. Thus, accurate manipulation of endogenous p53 activity will be of great value for both basic and clinical studies. Here, we report the small molecule G5 as a novel p53 inhibitor that can decrease the activity of $\mathrm{p} 53$ protein without affecting the proliferative capacity of MEF and ES cells.

Although several small compound inhibitors for p53 are available, they mostly impede on the normal growth of cells while repressing p53 activity. For example, the inhibitors Dicoumarol and HSP90 induce proteasomal degradation of the p53 protein ${ }^{[15-17]}$. The p53 inhibitor Pifithrin-a also globally blocks p53-dependent transcriptional activation ${ }^{[18,19]}$. Such complete abolishment of p53 activity can alter the overall expression of p53 downstream genes, resulting in abnormal cell growth and an increased risk of cancer. Thus, compounds
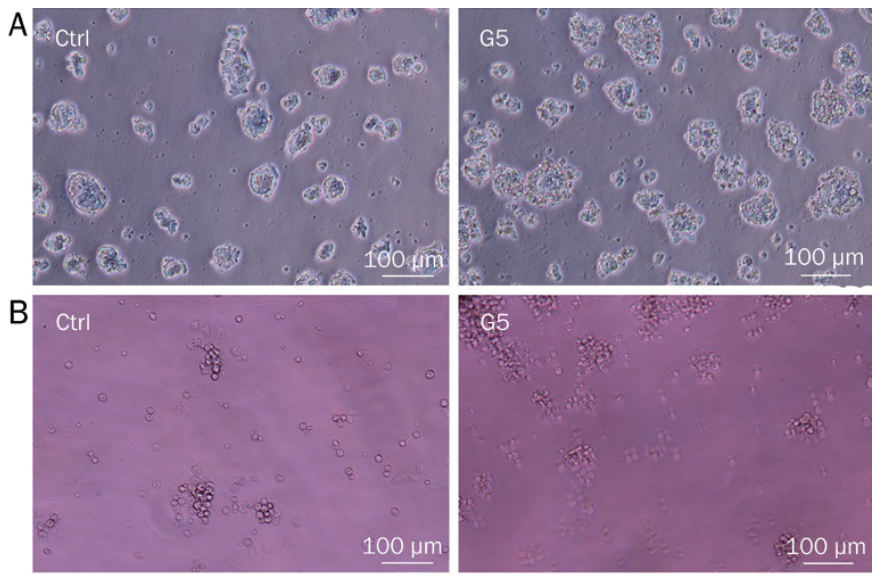

C

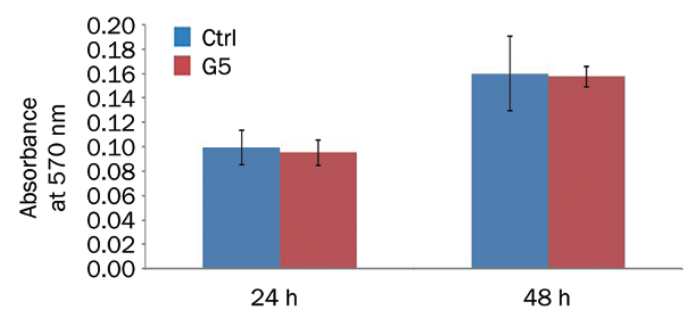

Figure 5. Effects of G5 on the morphology and proliferation rate of ES cells. (A) The morphology of ES cells with and without G5 treatment after $24 \mathrm{~h}$ of serum starvation. (B) The morphology of ES cells with and without $\mathrm{G} 5$ treatment after $48 \mathrm{~h}$ of serum starvation. (C) Examination of the cell proliferation rate on ES cells treated with G5 for $24 \mathrm{~h}$ and $48 \mathrm{~h}$. The number of viable cells was determined using the MTT assay.

that can modulate p53 activity and, at the same time, maintain normal cell behavior are desirable. The small compound G5 was identified in this study and partially meets these requirements. We have demonstrated that in MEF and ES cells, the application of G5 significantly modulated the expression of p53 downstream genes and did not cause any observable defects in the cells.

Recent studies have shown that repression of p53 activity can preserve stem cell self-renewal and promote iPS cell generation. Thus, modulation of p53 by G5 may also be useful in stem cell related studies. In our pilot experiment, we observed that the expression of many p53 downstream genes were altered, which is consistent with the inhibitory effect of p53 under G5 treatment. Because some p53 downstream genes, such as $\mathrm{p} 21^{[29-31]}, \mathrm{klf}^{[32]}$, were also activated via p53independent pathways, it is reasonable to suggest that some of these pathways exhibit expression changes that do not fully follow the expected pattern as they were solely regulated by p53. Consistent with previous reports of the negative roles of p53 in the promotion of ES cell pluripotency, we observed that the expression of several vital pluripotent factors were slightly upregulated in G5-treated ES cells. Moreover, similar to the results observed in MEF cells, these G5-treated mouse ES cells also demonstrated normal ES cell morphology and proliferation rate.

In summary, we identified a small compound, G5, that can inhibit p53 activity and simultaneously preserve the nor- 
mal growth and proliferation of cells. G5 is therefore a new compound for studies of p53-mediated cell manipulation. G5 causes less damage to cells and potentially has broader applications than currently available p53-inhibitory small molecules.

\section{Acknowledgements}

This study was supported by grants from the "Strategic Priority Research Program" of the Chinese Academy of Sciences (Grant № XDA01020105), the 973 program of China (2011CBA01101) and the 863 program of China (2011AA020108).

\section{Author contribution}

Xiu-jie WANG, Qi ZHOU, Liu WANG, and Xin LIU contributed to the study design; Ying ZHANG, Man TONG, Dongfang XIE, Dong-hui BAI, and Xin LIU performed the research; Xin LIU contributed to the drug design; Ying ZHANG performed the cell signaling assays; Man TONG, Dong-fang XIE, Shao-fang REN, and Dong-hui BAI performed the cell culture and proliferation assays; Xiu-ying LIU and Guan-zheng LUO performed the microarray data analysis; and Xiu-jie WANG, Xin LIU, Ying ZHANG, and Man TONG wrote the manuscript.

\section{References}

1 Vousden $\mathrm{KH}$, Prives C. Blinded by the light: the growing complexity of p53. Cell 2009; 137: 413-31.

2 Vogelstein B, Lane D, Levine AJ. Surfing the p53 network. Nature 2000; 408: 307-10.

3 Vousden KH, Lu X. Live or let die: the cell's response to p53. Nat Rev Cancer 2002; 2: 594-604.

4 Li M, He Y, Dubois W, Wu X, Shi J, Huang J. Distinct regulatory mechanisms and functions for p53-activated and p53-repressed DNA damage response genes in embryonic stem cells. Mol Cell 2012; 46: 30-42.

5 Hong H, Takahashi K, Ichisaka T, Aoi T, Kanagawa O, Nakagawa M, et al. Suppression of induced pluripotent stem cell generation by the p53-p21 pathway. Nature 2009; 460: 1132-5.

6 Li M, Huang J. A new puzzling role of p53 in mouse embryonic stem cells. Cell Cycle 2010; 9: 1669-70.

7 Lin T, Chao C, Saito S, Mazur SJ, Murphy ME, Appella E, et al. p53 induces differentiation of mouse embryonic stem cells by suppressing Nanog expression. Nat Cell Biol 2005; 7: 165-71.

8 Maimets T, Neganova I, Armstrong L, Lako M. Activation of p53 by nultin leads to rapid differentiation of human embryonic stem cells. Oncogene 2008; 27: 5277-87.

9 Qin H, Yu T, Qing T, Liu Y, Zhao Y, Cai J, et al. Regulation of apoptosis and differentiation by p53 in human embryonic stem cells. J Biol Chem 2007; 282: 5842-52.

10 Marion RM, Strati K, Li H, Murga M, Blanco R, Ortega S, et al. A p53mediated DNA damage response limits reprogramming to ensure iPS cell genomic integrity. Nature 2009; 460: 1149-53.

11 Zhao Y, Yin X, Qin H, Zhu F, Liu H, Yang W, et al. Two supporting factors greatly improve the efficiency of human iPSC generation. Cell Stem Cell 2008; 3: 475-9.

12 Bykov VJN, Selivanova G, Wiman KG. Small molecules that reactivate mutant p53. Eur J Cancer 2003; 39: 1828-34.

13 Wiman KG. Strategies for therapeutic targeting of the p53 pathway in cancer. Cell Death Differ 2006; 13: 921-6.

14 Nayak SK, Panesar PS, Kumar H. p53-induced apoptosis and inhibitors of p53. Curr Med Chem 2009; 16: 2627-40.

15 Asher G, Lotem J, Cohen B, Sachs L, Shaul Y. Regulation of p53 stability and p53-dependent apoptosis by NADH quinone oxidoreductase 1. Proc Natl Acad Sci U S A 2001; 98: 1188-93.

16 Asher G, Lotem J, Kama R, Sachs L, Shaul Y. NQ01 stabilizes p53 through a distinct pathway. Proc Natl Acad Sci U S A 2002; 99: 3099-104.

17 Asher G, Lotem J, Sachs L, Kahana C, Shaul Y. Mdm-2 and ubiquitinindependent p53 proteasomal degradation regulated by NQ01. Proc Natl Acad Sci U S A 2002; 99: 13125-30.

18 Komarov PG, Komarova EA, Kondratov RV, Christov-Tselkov K, Coon JS, Chernov MV, et al. A chemical inhibitor of p53 that protects mice from the side effects of cancer therapy. Science 1999; 285: 1733-7.

19 Komarova EA, Gudkov AV. Suppression of p53: a new approach to overcome side effects of antitumor therapy. Biochemistry 2000; 65: 41-8.

20 Vassilev LT, Vu BT, Graves B, Carvajal D, Podlaski F, Filipovic Z, et al. In vivo activation of the $\mathrm{p} 53$ pathway by small-molecule antagonists of MDM2. Science 2004; 303: 844-8.

21 Abdelalim EM, Tooyama I. The p53 inhibitor, pifithrin- $\alpha$, suppresses self-renewal of embryonic stem cells. Biochem Biophys Res Commun 2012; 420: 605-10.

22 Tong M, Lv Z, Liu L, Zhu H, Zheng QY, Zhao XY, et al. Mice generated from tetraploid complementation competent iPS cells show similar developmental features as those from ES cells but are prone to tumorigenesis. Cell Res 2011; 21: 1634-7.

23 Zhao XY, Li W, Lv Z, Liu L, Tong M, Hai T, et al. iPS cells produce viable mice through tetraploid complementation. Nature 2009; 461: 86-90.

24 Wu H, Chen Y, Liang J, Shi B, Wu G, Zhang Y, et al. Hypomethylationlinked activation of PAX2 mediates tamoxifen-stimulated endometrial carcinogenesis. Nature 2005; 438: 981-7.

25 Plasilova M, Schonmeyr B, Fernandez J, Clavin N, Soares M, Mehrara BJ. Accelerating stem cell proliferation by down-regulation of cell cycle regulator p21. Plast Reconstr Surg 2009; 123: 149S-157S.

26 Sandberg M, Källström M, Muhr J. Sox21 promotes the progression of vertebrate neurogenesis. Nat Neurosci 2005; 8: 995-1001.

27 Bourillot PY, Savatier P. Krüppel-like transcription factors and control of pluripotency. BMC Biol 2010; 8: 125.

28 Tutter AV, Kowalski MP, Baltus GA, lourgenko V, Labow M, Li E, et al. Role for Med12 in regulation of Nanog and Nanog target genes. J Biol Chem 2009; 284: 3709-18.

29 Macleod KF, Sherry N, Hannon G, Beach D, Tokino T, Kinzler K, et al. p53-dependent and independent expression of p21 during cell growth, differentiation, and DNA damage. Genes Dev 1995; 9: 93544.

30 Huo JX, Metz SA, Li GD. p53-independent induction of p21 $21^{\text {waf } 1 / \text { cip } 1}$ contributes to the activation of caspases in GTP-depletion-induced apoptosis of insulin-secreting cells. Cell Death Differ 2004; 11: 99109.

31 Aliouat-Denis CM, Dendouga N, Van den Wyngaert I, GoehImann $\mathrm{H}$, Steller $\mathrm{U}$, van de Weyer I, et al. p53-independent regulation of p21 ${ }^{\text {Waf1/Cip1 }}$ expression and senescence by Chk2. Mol Cancer Res 2005; 3: 627-34.

32 Hall J, Guo G, Wray J, Eyres I, Nichols J, Grotewold L, et al. Oct4 and LIF/Stat3 additively induce Krüppel factors to sustain embryonic stem cell self-renewal. Cell Stem Cell 2009; 5: 597-609.

This work is licensed under the Creative Commons Attribution-NonCommercial-No Derivative Works 3.0 Unported License. To view a copy of this license, visit http://creativecommons.org/licenses/ by-nc-nd/3.0/ 